\title{
PENGARUH NILAI PERUSAHAAN, TINGKAT UTANG, DAN KESULITAN KEUANGAN TERHADAP KEPUTUSAN HEDGING
}

\author{
Edon Ramdani $^{1}$, Putri Oktaviani ${ }^{2}$ \\ Program Studi S1 Akuntansi Fakultas Ekonomi Universitas Pamulang \\ edonramdani9@gmail.com, putrioktaviani867@gmail.com
}

\begin{abstract}
The purpose of this research is to investigate the influence of firm value, debt level, and financial distress on hedging decisions. The population of this research is the manufacturing company sector various industrial that listed in the Indonesia Stock Exchange (IDX) in 2015-2019. The sample used in this research consist of 12 manufacturing companies in the various industrial sector. The sampling method is non probability sampling with the sampling technique using purposive sampling. The analysis is performed by using regression analysis logistic. The results of the research with the logistic regression test show that in the LR test simultaneously all independent variables, namely Firm Value, Debt Level, and Financial Distress together have a effect on hedging decisions with a significant value less than 0.05, namely $0.004023<0,05$. In the Z-score Test Statistic (partially), the Firm Value with a significant value of 0,0527 > 0.05, it does not affect the Hedging Decision. The Debt Level with a significant value of $0,0218<0.05$ has effect on hedging decisions. Financial distress with a significant value of 0,0018< 0.05 , it has a significant effect on hedging decisions. The McFadden 22 test for the three variables obtained $16 \%$ while the remaining $84 \%$ was explained by other variables not explained in this research.
\end{abstract}

Keywords: Firm Value, Debt Level, Financial Distress, Hedging Decisions.

\section{PENDAHULUAN}

Persaingan dunia usaha membuat beberapa perusahaan di berbagai negara semakin meningkatkan perdagangan internasionalnya. Indonesia adalah salah satu negara yang perusahaannya ikut bergabung dalam lini perdagangan internasional. Tentunya, transaksi ekspor dan impor tidak pernah terlepas dari hal tersebut. Transaksi perusahaan tidak hanya dilakukan secara tunai, akibatnya muncul utang ataupun piutang yang mengakibatkan perusahaan mengalami kerugian ataupun keuntungan. Selain itu, kegiatan perdagangan internasional juga mengharuskan perusahaan menggunakan mata uang yang berbeda, dimana didalamnya terdapat risiko perubahan nilai tukar mata uang. Indonesia mengalami pelemahan nilai rupiah terhadap US dollar selama lima tahun terakhir.

Salah satu cara perusahaan untuk mengurangi risiko kurs yaitu dengan melakukan hedging menggunakan instrument derivatif (Kussulistyanti, 2016). Derivatif yang dimaksud yaitu instrument keuangan yang nilainya didasarkan pada aset seperti obligasi, saham, tingkat suku bunga, mata uang asing, dan aset lainnya. Tidak semua perusahaan yang melakukan transaksi kurs valuta asing melakukan hedging, meskipun telah mengetahui manfaat hedging untuk mengurangi risiko nilai tukar.

Variabel independen pertama yang mampu mengidentifikasi keputusan hedging adalah Nilai Perusahaan. Penelitian yang dilakukan Ahmad \& Haris (2012) dan Reni \& Purnawati (2016) mendapatkan hasil bahwa market to book value memiliki pengaruh yang signifikan terhadap keputusan hedging. Sedangkan penelitian yang dilakukan oleh Indra (2017) dan Prasetyo (2018) mendapatkan hasil bahwa market to book value tidak terbukti berpengaruh terhadap keputusan hedging.

Selanjutnya, variabel independen kedua yang mampu mengidentifikasi variabel keputusan 
hedging adalah tingkat utang. Penelitian yang dilakukan oleh Iqbal (2015), Krisdian \& Badjra (2017), dan Ariani (2017) menyatakan bahwa tingkat utang memiliki pengaruh yang positif signifikan terhadap keputusan hedging. Sedangkan penelitian Salindri (2018) dan Wulandari (2018) menyatakan bahwa tingkat utang tidak berpengaruh terhadap keputusan hedging.

Variabel independen terakhir dalam penelitian ini adalah Kesulitan keuangan yang dirumuskan dalam rumus Z Score yang dikemukakan oleh Edward I. Altman. Dalam penelitian Hartono (2019) menyatakan bahwa kesulitan keuangan berpengaruh signifikan terhadap pengambilan keputusan hedging, Krisdian \& Badjra (2017) menghasilkan bahwa financial distress memiliki pengaruh positif signifikan terhadap keputusan hedging, hal serupa juga dihasilkan dalam penelitian Anniyati (2020) dan Amaliyah (2020) yang menyatakan variabel financial distress berpengaruh positif terhadap keputusan hedging. Namun berbeda dengan penelitian yang dilakukan oleh Wulandari (2018) yang menyatakan financial distress tidak berpengaruh terhadap keputusan hedging.

Penelitian ini bertujuan untuk mengetahui pengaruh nilai perusahaan, tingkat utang, dan kesulitan keuangan terhadap keputusan hedging.

\section{TINJAUAN PUSTAKA}

\section{(1) Teori Sinyal (Signalling Theory)}

Teori sinyal menjelaskan hubungan antara pemberi informasi perusahaan dan persepsi investor dimana teori sinyal menurut Prasisiwi (2015) menjelaskan bagaimana pentingnya informasi yang dikeluarkan oleh perusahaan terhadap keputusan investasi pihak luar. Informasi simetris adalah kesamaan informasi mengenai prospek suatu perusahaan yang diterima oleh semua pihak baik manajer maupun investor. Namun pada kenyataannya, para manajer memiliki informasi yang lebih baik dari pada investor yang disebut dengan asimetri informasi. Adanya asimetri informasi yang dimiliki perusahaan membuat perusahaan dalam membiayai peluang pertumbuhannya memilih pendanaan eksternal berupa utang yang kemudian menimbulkan risiko bagi perusahaan dan membuat perusahaan melakukan hedging untuk melindungi perusahaannya

\section{(2) Pecking Order Theory}

Menurut Jinkar (2013) mengemukakan adanya urutan sumber dana dalam pembuatan keputusan pendanaan perusahaan. Berdasarkan teori, ketika membutuhkan dana untuk keperluan pembiayaan investasi perusahaan, seharusnya perusahaan membiayai kesempatan investasi dengan dana internal terlebih dahulu. Jika keperluan untuk investasi tidak bisa didapat dari pendanaan internal, maka perusahaan akan menggunakan pendanaan eksternal dari utang sebagai sumber pendanaan kedua, dan ekuitas sebagai sumber pendanaan terakhir.

\section{(3) Teori Paritas Daya Beli}

Teori paritas daya beli menyatakan bahwa nilai tukar akan menyesuaikan diri dari waktu ke waktu untuk mencerminkan selisih inflansi antar dua negara sehingga daya beli konsumen untuk membeli produk - produk domestik akan sama dengan daya beli konsumen untuk membeli produk - produk asing (Madura, 2006). Paritas daya beli menunjukkan secara langsung bahwa perubahan nilai tukar mata uang berhubungan dengan perbedaan inflasi yang berlaku dari satu negara ke negara lain. Kerangka penelitian dalam penelitian ini digambarkan seperti gambar dibawah. 


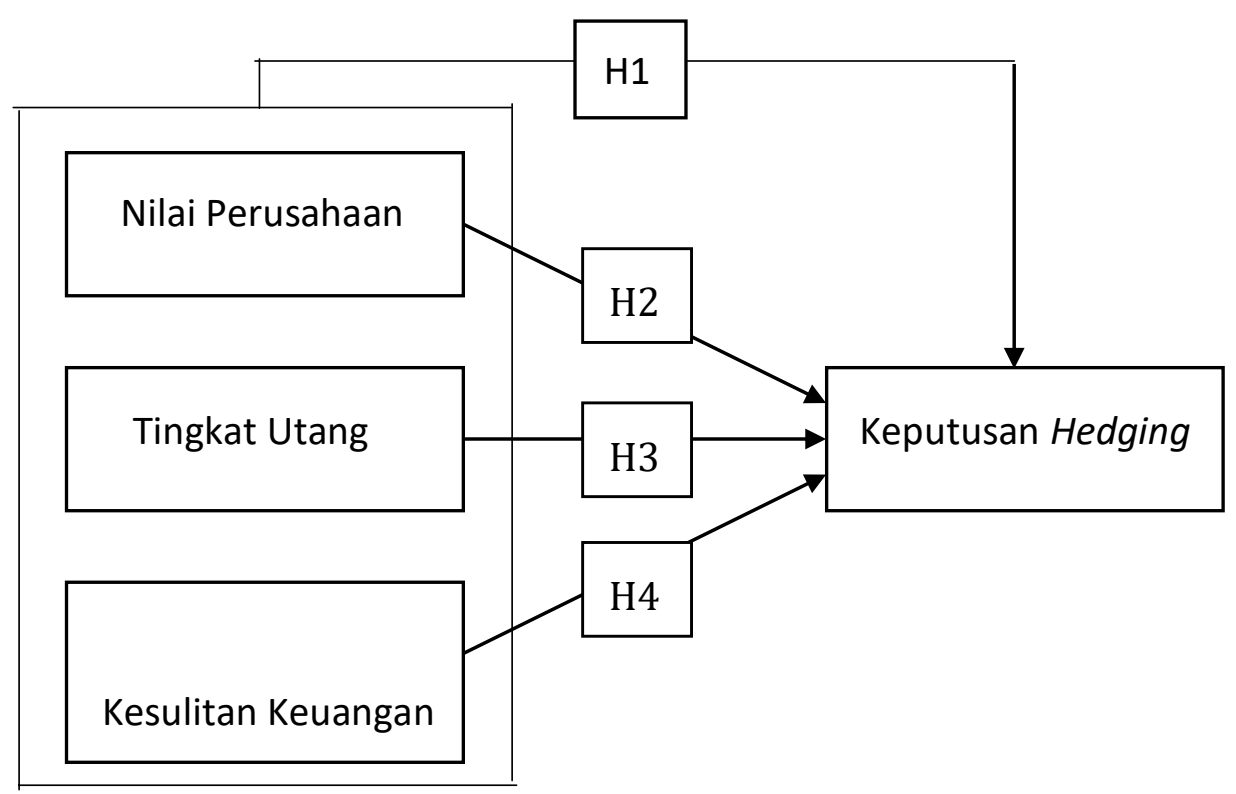

Gambar 1. Kerangka Penelitian

Hipotesis berdasarkan model kerangka penelitian diatas adalah sebagai berikut:

H1 : Nilai Perusahaan, Tingkat Utang, dan Kesulitan Keuangan berpengaruh terhadap Keputusan Hedging.

H2 : Nilai Perusahaan berpengaruh terhadap Keputusan Hedging.

H3 : Tingkat utang berpengaruh terhadap keputusan hedging

H4 : Kesulitan Keuangan berpengaruh terhadap keputusan hedging

\section{METODE}

Subjek penelitian. Subjek yang digunakan oleh peneliti di dalam penelitian ini adalah perusahaan manufaktur sektor aneka industri yang terdaftar di Bursa Efek Indonesia (BEI) periode 2015 - 2019.

\section{Objek Penelitian.}

Dalam penelitian ini menggunakan data sekunder yang diperoleh dari laporan keuangan perusahaan periode 2015 - 2019 yang bersumber dari Bursa Efek Indonesia, yaitu www.idx.co.id dan daftar perusahaan manufaktur sektor aneka industri berasal dari halaman surel serupa.

\section{Metode Sampling.}

Metode yang digunakan untuk memilih sampel yaitu purposive sampling method dimana metode ini menggunakan beberapa ketentuan atau kriteria untuk memilih sampel yang akan diteliti. Perusahaan yang akan diteliti pada penelitian ini berjumlah 12 perusahaan maunufaktur sektor aneka industri dari periode waktu yang digunakan sebanyak 5 tahun.

\section{Operasionalisasi Variabel.}

1. Nilai Perusahaan. Nilai Perusahaan dalam penelitian ini menggunakan proksi market to book value (MTBV). Sedangkan MTBV adalah rasio antara harga pasar dengan nilai buku. Rasio MTBV yang digunakan dalam penelitian ini membandingkan harga pasar per lembar saham dengan nilai buku per lembar saham yang dimiliki oleh perusahaan manufaktur sektor aneka industri yang terdaftar di BEI periode 2015-2019. Dengan rumus sebagai berikut: 


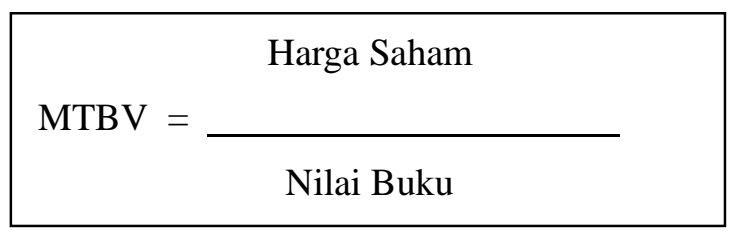

2. Tingkat Utang. Tingkat utang merupakan rasio yang menghitung seberapa jauh dana yang disediakan oleh kreditur juga sebagai rasio yang membandingkan rotal utang terhadap keseluruhan asset suatu perusahaan. Semakin besar utang perusahaan, semakin besar biaya bunga yang harus dibayar, semakin tinggi kemungkinan perushaaan mengalami kegagalan bayar dan kebangkrutan (Kussulistyanti, 2016). Rasio ini mengggunakan DAR dengan rumus

Debt ratio $=\frac{\text { Total hutang }}{\text { Total aktiva }} \times 100 \%$

3. Kesulitan Keuangan. Financial Distress juga diartikan sebagai suatu kondisi yang dialami suatu perusahaan yang tidak dapat memenuhi kebutuhan perusahaan dan kewajiban-kewajibannya yang berada dalam kondisi tidak aman yang diprediksi akan mengalami kegagalan (Wulandari, 2018). Pengukuran financial distress dapat diterangkan dari perhitungan Z-Score yang dikemukakan oleh Edward I. Altman. Secara matematis financial distress dapat diformulasikan dengan metode Z-Score sebagai berikut:

$\mathrm{Z}=1,2(\mathrm{WCTA})+1,4($ RETA $)+3,3($ EBITTA $)+0,6(\mathrm{MVEBVL})+1$ (STA)

4. Keputusan Hedging/ Lindung nilai. Lindung nilai berarti melindungi suatu investasi yang sedang dijalankan atau menguragi maupun meniadakan risiko investasi yang sedang dijalankan. Rumus yang digunakan untuk menghitung hedging yaitu dengan menggunakan instrumen derivatif. Hedging dinyatakan dengan variabel dummy, apabila perusahaan menggunakan hedging maka diberi nilai angka 1 dan diberi angka 0 untuk perusahaan yang tidak menggunakan aktivitas hedging.

\section{HASIL DAN PEMBAHASAN}

\section{Uji Statistik}

Analisis data yang digunakan dalam penelitian ini berupa analisis statistik deskriptif dan analisis regresi logistik untuk menguji pengaruh nilai perusahaan, tingkat utang, dan kesulitan keuangan terhadap keputusan hedging. Uji yang dilakukan pada penelitian ini yaitu Uji Analisis Statistik Desktiptif, Uji Multikolonieritas, Uji Regresi Logistik, Uji Kelayakan Model (Hosmer and Lemeshow test), Uji Koefisien $R^{2}$ McFadden, Uji LR Statistik, Uji Z Statistik, dan Odds Ratio. 
(1) Hasil Uji Analisis Statistik Desktriptif.

\begin{tabular}{|c|c|c|c|c|}
\hline & $\mathbf{H}$ & NP & $\mathbf{T U}$ & KK \\
\hline Mean & 0.583333 & 1.193500 & 0.395167 & 2.245833 \\
\hline Median & 1.000000 & 0.840000 & 0.380000 & 2.005000 \\
\hline Maximum & 1.000000 & 4.760000 & 0.730000 & 4.410000 \\
\hline Minimum & 0.000000 & 0.050000 & 0.090000 & 0.410000 \\
\hline Std. Dev. & 0.497167 & 1.172660 & 0.170329 & 0.903540 \\
\hline Skewness & -0.338062 & 1.392972 & 0.432973 & 0.244533 \\
\hline Kurtosis & 1.114286 & 3.936894 & 2.541214 & 2.747228 \\
\hline Jarque-Bera & 10.03265 & 21.59812 & 2.400868 & 0.757699 \\
\hline Probability & 0.006629 & 0.000020 & 0.301064 & 0.684649 \\
\hline Sum & 35.00000 & 71.61000 & 23.71000 & 134.7500 \\
\hline Sum Sq. Dev. & 14.58333 & 81.13277 & 1.711698 & 48.16666 \\
\hline Observations & 60 & 60 & 60 & 60 \\
\hline
\end{tabular}

Dapat dilihat dari tabel di atas hasil dari desktriptif variabel independen Nilai Perusahaan menunjukkan nilai minimum sebesar 0.050000 yang dimiliki oleh PT. Nusantara Inti Corpora dan nilai maksimum sebesar 4.760000 yang dimiliki oleh PT. Selamat Sempurna. Nilai rata-rata variabel Nilai Perusahaan sebesar 1.193500 dan standar deviasi sebesar 1.172660. Variabel independen Tingkat utang memiliki nilai minimum sebesar 0.090000 yang dimiliki oleh PT. Indospring dan nilai maksimum sebesar 0.730000 yang dimiliki oleh PT. Jembo Cable Company. Nilai rata-rata variabel Tingkat Utang sebesar 0.395167 dan standar deviasi sebesar 0.170329. Variabel independen Kesulitan Keuangan memiliki nilai minimum sebesar 0.410000 yang dimiliki oleh PT. Nusantara Inti Corpora dan nilai maksimum sebesar 4.410000 yang dimiliki oleh PT. Star Petrochem. Nilai rata-rata variabel Kesulitan Keuangan sebesar 2.245833 dan standar deviasi sebesar 0.903540 .

(2). Hasil Uji Multikolinearitas

\begin{tabular}{|c|rcc|}
\hline NILAI PERUSAHAAN & 1.000000 & -0.160608 & 0.474765 \\
\hline TINGKAT UTANG & -0.160608 & $1.00(000)$ & -0.531057 \\
\hline KESULITAN KEUANGAN & 0.474765 & -0.531057 & 1.000000 \\
\hline
\end{tabular}

Sumber : diolah menggunakan Eviews9

Menurut Widarjono (2013), jika nilai koefisien korelasi berada di atas 0,85 maka terindikasi adanya multikolinearitas dalam model. Berdasarkan tabel 4.4 koefisien korelasi yang dihasilkan adalah kurang dari 0,85 maka artinya variabel independen tidak memiliki masalah multikolinearitas. 
(3) Hasil Uji Analisis Logistik

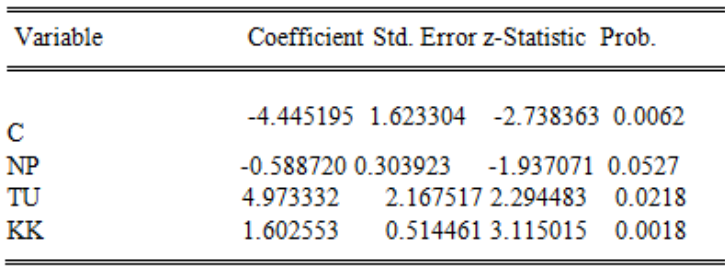

\begin{tabular}{|c|c|c|c|}
\hline McFadden R-squared & 0.163236 & \multicolumn{2}{|c|}{ Mean dependent var 0.583333} \\
\hline S.D. dependent var & 0.497167 & \multirow{2}{*}{\multicolumn{2}{|c|}{$\begin{array}{l}\text { S.E. of regression } 0.451908 \\
\text { Sum squared resid } 11.43636\end{array}$}} \\
\hline Akaike info criterion & 1.269983 & & \\
\hline Schwarz criterion & 1.409606 & Log likelihood & -34.09949 \\
\hline Hannan-Quinn criter. & 1.324597 & Deviance & 68.19897 \\
\hline Restr. deviance & 81.50319 & Restr. log likelihood & \multirow{3}{*}{-0.568325} \\
\hline LR statistic & 13.30422 & \multirow[t]{2}{*}{ Avg. $\log$ likelihood } & \\
\hline Prob(LR statistic) 0.0 & 04023 & & \\
\hline Obs with Dep & 25 & \multirow[t]{2}{*}{ Total obs } & \multirow[t]{2}{*}{60} \\
\hline Obs with Dep=1 & 35 & & \\
\hline
\end{tabular}
berikut:

Persamaan model untuk analisis regresi logistik yang terbentuk adalah sebagai $\mathrm{H}=-4.44519-0.58872(\mathrm{NP})+4.97333(\mathrm{TU})+1.60255(\mathrm{KK})$ Keterangan :

1. $\mathrm{H}=$ Hedging pada perusahaan manufaktur sektor aneka industri tahun $2015-2019$.

2. $\quad \mathrm{NP}=$ Nilai Perusahaan pada perusahaan manufaktur sektor aneka industri tahun 2015 2019.

3. $\mathrm{TU}=$ Tingkat $U$ tang pada perusahaan manufaktur sektor aneka industri tahun $2015-2019$.

4. $\mathrm{KK}=$ Kesulitan Keuangan pada perusahaan manufaktur sektor aneka industri tahun 2015 2019.

Jika konstanta sebesar -4.445195 , artinya jika NP, TU, dan KK nol artinya perusahaan mempunyai nilai sebesar -4.445195 .

Koefisien regresi variabel nilai perusahaan yang diproksikan dengan Market to Book Value (MTBV) sebesar -0.588720 , artinya apabila variabel lain anggapannya tetap dan variabel profitabilitas naik satu satuan maka hedging akan naik sebesar 0.588720. Koefisien regresi variabel tingkat utang yang diproksikan dengan Debt to Asset Ratio (DAR) sebesar 4.973332, artinya apabila variabel lain anggapannya tetap dan variabel profitabilitas naik satu satuan maka hedging akan naik sebesar 4.973332. Koefisien regresi variabel kesulitan keuangan yang diproksikan dengan Altman Z-Score sebesar 1.602553 artinya apabila variabel lain anggapannya tetap dan variabel profitabilitas naik satu satuan maka hedging akan naik sebesar 1.602553.

(4). Hasil Uji Kelayakan Model (Hosmer and Lemeshow test)

$$
\begin{array}{llll}
\text { H-L Statistic } & 8.4851 \quad \text { Prob. Chi-Sq(8) } & 0.3876
\end{array}
$$

Sumber: Software Eviews 9 (Data diolah Penulis, 2021)

Berdasarkan tabel 4.6 menunjukkan besarnya nilai statistik Hosmer and Lemeshow Goodness of Fit sebesar 8.4851 dengan probabilitas signifikansi 0.3876 yang nilainya lebih besar dari 0.05 maka hipotesis nol diterima dan berarti model mampu memprediksi nilai observasinya. Hal ini berarti model regresi layak dipakai untuk analisis selanjutnya. 
(5). Hasil Uji Akurasi Model

Expectation-Prediction Evaluation for Binary

Specification Equation: UNTITLED

Date: 07/21/21 Time: 09:17 Success cutoff: C 0.5

\section{Constant}

Estimated Equation Probably

Dep $=0$ Dep $=1 \quad$ Total Dep $=0 \quad$ Dep $=1 \quad$ Total

\begin{tabular}{crrrrrr}
\hline \hline $\begin{array}{c}\mathrm{P}(\text { Dep }=1)< \\
=\mathrm{C}\end{array}$ & 16 & 8 & 24 & 0 & 0 & 0 \\
$\mathrm{P}($ Dep $=1)>$ & & & & & & \\
$\mathrm{C}$ & 9 & 27 & 36 & 25 & 35 & 60 \\
Total & 25 & 35 & 60 & 25 & 35 & 60 \\
Correct & 16 & 27 & 43 & 0 & 35 & 35 \\
\% Correct & $\mathbf{6 4 . 0 0}$ & 77.14 & 71.67 & 0.00 & 100.00 & 58.33 \\
\% Incorrect & 36.00 & 22.86 & 28.33 & 100.00 & 0.00 & 41.67 \\
Total Gain* & 64.00 & -22.86 & 13.33 & & & \\
Percent & & & & & & \\
Gain** & 64.00 & NA & 32.00 & & & \\
\hline
\end{tabular}

Berdasarkan Expectation Prediction diatas, jumlah incoreect sebesar 64\% sehingga menghasilkan penelitian ini layak diuji menggunakan uji ini

(6). Hasil Uji Koefisien Determinasi (R2 McFadden)

\begin{tabular}{lcll} 
McFadden R-squared & $\mathbf{0 . 1 6 3 2 3 6}$ & Mean dependent var & 0.583333 \\
S.D. dependent var & 0.497167 & S.E. of regression & 0.451908 \\
Akaike info criterion & 1.269983 & Sum squared resid & 11.43636 \\
Schwarz criterion & 1.409606 & Log likelihood & -34.09949 \\
Hannan-Quinn criter. & 1.324597 & Deviance & 68.19897 \\
Restr. deviance & 81.50319 & Restr. log likelihood & -40.75160 \\
LR statistic & 13.30422 & Avg. log likelihood & -0.568325 \\
Prob(LR statistic) & 0.004023 & & \\
\hline
\end{tabular}

Sumber: Data diolah menggunakan Eviews 9

Berdasarkan tabel 4.7 diketahui hasil estimasi nilai R2 McFadden (R2MCF) sebesar 0.163236 maka berarti variabel independen dalam model yaitu Nilai Perusahaan (NP), Tingkat Utang (TU), dan Kesulitan Keuangan (KK) mampu menjelaskan pengaruh kepada Keputusan Hedging sebesar $16 \%$ dan selebihnya $84 \%$ dijelaskan oleh variabel lain di luar model penelitian ini.

(7). Hasil Uji Likelihood Ratio (LR Statistic)

\section{LR statistic $\quad \mathbf{1 3 . 3 0 4 2 2}$ Avg. log likelihood $\quad-0.568325$ \\ Prob(LR statistic) $\quad \mathbf{0 . 0 0 4 0 2 3}$}

Sumber: Data diolah menggunakan eviews 9

Hasil uji LR dalam penelitian yang terlihat dari tabel 4.8 diperoleh nilai LR statistic (chi square) sebesar 13.30422 dengan nilai probabilitasnya sebesar 0.004023 yang nilainya lebih kecil dari 0.05 , maka keputusannya yaitu menolak Ho dan menerima $\mathrm{H} \alpha$ yang berarti bahwa semua variabel independen secara bersamasama dapat mempengaruhi variabel dependen. 
(8). Hasil Uji Z Statistik

\begin{tabular}{ccccc} 
Variable & Coefficient & Std. Error & z-Statistic & \multicolumn{2}{l}{ Prob. } \\
\hline \hline & -4.445195 & 1.623304 & -2.738363 & 0.0062 \\
C & & & & \\
NP & -0.588720 & 0.303923 & -1.937071 & 0.0527 \\
TU & 4.973332 & 2.167517 & 2.294483 & 0.0218 \\
KK & 1.602553 & 0.514461 & 3.115015 & 0.0018
\end{tabular}

Sumber: Data diolah menggunakan Eviews 9

Uji Z dilakukan dengan membandingkan nilai probabilitas terhadap $\alpha$, jika nilai probabilitas $<\alpha$, maka Ho ditolak artinya bahwa variabel independen mempengaruhi variabel dependen. Sedangkan jika nilai probabilitas $>\alpha$, maka Ho diterima artinya bahwa variabel independen tidak mempengaruhi variabel dependen (Gujarati, 2012).

Berdasarkan tabel 4.9 dapat terlihat bahwa hasil probabilitas nilai perusahaan sebesar $0.0527>0.05$, yang berarti tidak berpengaruh signifikan terhadap keputusan hedging. Tingkat utang sebesar $0.0218<0.05$, yang berarti variabel tersebut berpengaruh terhadap keputusan hedging. Hasil probabilitas kesulitan keuangan sebesar $0.0018<0.05$ yang artinya variabel tersebut berpengaruh siginifikan terhadap keputusan hedging.

(9). Hasil Uji Odds Ratio

Variable Coefficient Std. Error Odds Ratio

\begin{tabular}{llll}
\hline \hline & & & \\
$\mathrm{C}$ & -4.445195 & 1.623304 & 0.011702 \\
$\mathrm{NP}$ & -0.588720 & 0.303923 & 0.554831 \\
$\mathrm{TU}$ & 4.973332 & 2.167517 & 144.9624 \\
$\mathrm{KK}$ & 1.602553 & 0.514461 & 4.970725 \\
\hline
\end{tabular}

Sumber: Data diolah menggunakan Eviews 9

Berdasarkan hasil diatas dapat disimpulkan bahwa untuk variabel nilai perusahaan, nilai odds ratio yang didapatkan sebesar 0.554831 yang berarti kenaikan satu unit nilai perusahaan maka akan menurunkan perusahaan menggunakan hedging sebanyak 0.554831. Untuk variabel tingkat utang, nilai odds ratio yang didapatkan sebesar 144.9624 yang berarti kenaikan satu unit tingkat utang maka akan meningkatkan perusahaan menggunakan hedging sebanyak 144.9624. Untuk variabel kesulitan keuangan, nilai odds ratio yang didapatkan sebesar 4.970725 yang berarti kenaikan satu unit kesulitan keuangan maka akan meningkatkan perusahaan menggunakan hedging sebanyak 4.970725. 


\section{SIMPULAN}

Hasil analisis dalam pengujian memperlihatkan bahwa Nilai Perusahaan, Tingkat Utang, dan Kesulitan Keuangan memiliki pengaruh secara simultan terhadap Keputusan Hedging. Hasil analisis dalam pengujian Z Statistik atau secara parsial memperlihatkan bahwa Nilai Perusahaan tidak memiliki pengaruh terhadap keputusan hedging. Hasil analisis selanjutnya memperlihatkan variabel Tingkat Utang memiliki pengaruh signifikan terhadap keputusan hedging. Variabel terakhir dalam penelitian yaitu Kesulitan Keuangan memiliki hasil berpengaruh terhadap keputusan hedging.

\section{SARAN}

1. Dalam penelitian ini menggunakan variable dependen keputusan hedging dan variable independen nilai perusahaan, tingkat utang, dan kesulitan keuangan. Diharapkan bagi peneliti selanjutnya menggunakan variable independen lain seperti current ratio, institutional ownership, managerial ownership, atau rasio keuangan lainnya

2. Dalam penelitian ini menggunakan sampel perusahaan manufaktur sector aneka industry. Bagi peneliti selanjutnya diharapkan menggunakan sampel perusahaan yang lebih banyak

3. Periode penelitian ini adalah tahun 2015-2019, diharapkan bagi peneliti berikutnya menggunakan tahunt erbaru agar mengikuti perkembangan ilmu dan bisnis

4. Penelitian ini menggunakan metoe regresi logistic dan software Eviews 9. Bagi peneliti selanjutnya diharapkan menggunakan metode dan software yang lebih memadai

\section{DAFTAR PUSTAKA}

Ahmad, Noryati and Haris, Balkis. 2012. Factors For Using Derivatives : Evidence From Malaysian Non-financial Companies. Research Journal of Finance and Accounting. 3(9):pp:79-89

Amaliyah, I., \& Anhar, M. (2020). Pengaruh Financial Distress, Growth Opportunity, Firm Size, Managerial Ownership Terhadap Pengambilan Keputusan Hedging .... Pengaruh Financial Distress ..., XX(Xx), 1-16. http://repository.stei.ac.id/1855/

Anisa. (2021). Pengaruh IFR dan Tingkat Pengungkapan Informasi Terhadap Nilai Perusahaan dengan Relevansi Nilai Sebagai Variabel Intervening. Jurnal Akuntansi Berkelanjutan Indonesia, 4(1), 53-72.

Anniyati, H., Hermanto. dan S. A. Hidayati. 2020. "Pengaruh Firm Size, Financial Distress, Debt Level, Dan Managerial Ownership Terhadap Keputusan Hedging Pada Perusahaan Manufaktur Yang Terdaftar Di Bursa Efek Indonesia.” Jmm Unram - Master of Management Journal 9(1): 28-41. ISSN : 2548-3919. Decree.

Ariani, N., \& Sudiartha, G. (2017). Pengaruh Leverage, Profitabilitas, Dan Likuiditas Terhadap Keputusan Hedging Perusahaan Sektor Pertambangan Di Bursa Efek Indonesia. E-Jurnal Manajemen, 6(1), 347-374

Bodie, Z., Kane, A., \& Marcus, J. (2014). Manajemen Portofolio dan Investasi (Edisi 9). Jakarta: Erlangga

Ernawati, Dewi dan Dini Widyawati. 2015. "Pengaruh Profitabilitas, Leverage, dan Ukuran Perusahaan Terhadap Nilai Perusahaan”. Jurnal Ilmu dan Riset Akuntansi. Vol. 04 No. 02. Surabaya

Fajar N. (2017). Determinasi Keputusan Hedging Pada Perusahaan Manufaktur Yang Terdaftar di BEI. Calyptra: Jurnal Ilmiah Mahasiswa Universitas Surabaya Vol.6 No.1 (2017). 6(1), 866-885 
Ghozali, Imam. 2013. Aplikasi Analisis Multivariate dengan Program IBM SPSS 21. Cetakan ketujuh. Semarang: Badan Penerbit Universitas Diponogoro

Gujarati, D. N. dan D. C. Porter. (2012). Dasar-Dasar Ekonometrika. Edisi Lima Buku Dua. Jakarta: Salemba Empat

Guniarti, F. 2014. "Faktor-Faktor Yang Mempengaruhi Aktivitas Hedging Dengan Instrumen Derivatif Valuta Asing." Jurnal Dinamika Manajemen 5(1): 64-79. Http://Journal.Unnes.Ac.Id/Nju/Index.Php/Jdm. ISSN : 2086-0668

Halim, A. (2015). Analisis Investasi di Aset Keuangan. Edisi Pertama. Jakarta : Mitra Wacana Media

Hanifah, O. E. (2013). PERSETUJUAN SKRIPSI Nama penyusun: Oktita Earning Hanifah Nomor Induk Mahasiswa: C2C009078

Hantono, n. u. (2018). pengantar akutansi. yogyakarta: Cv. Budi utama

Iqbal, Zaid. 2015. Financial Distress around Introduction of Hedging in the Oil and Gas Industry. International Journal of Business, 20(1): 79-89

Krisdian, N., \& Badjra, I. (2017). Pengaruh Ukuran Perusahaan, Tingkat Hutang, Dan Kesulitan Keuangan Terhadap Keputusan Hedging Pada Perusahaan Manufaktur

Indonesia. E-Jurnal Manajemen Universitas Udayana, 6(3), 247325

Kuncoro, Mudrajad. (2009). Manajamen Keuangan Internasional: Pengantar Ekonomi dan Bisnis Global. Yogyakarta: BPFE Yogyakarta.

Kussulistyanti, M. J. W. A., \& Mahfudz. (2016). Analisis Faktor-Faktor Yang Memengaruhi Keputusan Hedging Dengan Derivatif Valuta Asing (Studi Pada Perusahaan NonFinansial yang Terdaftar Di Bursa Efek Indonesia Periode Tahun 2011-2014). Diponegoro Journal Of Management, 5(3), 1-14. http://ejournal-

s1.undip.ac.id/index.php/management

Lesmana, N. V. D., \& Musdholifah. (2019). Faktor-Faktor Internal Keputusan Hedging dan Dampaknya pada Nilai Perusahaan Miscellaneous Industry. Jurnal Ilmu Manajemen (JIM), 7, 857-867.

Madura, Jeff (2006). Keuangan Perusahaan Internasional, diterjemahkan oleh Yanivi S. Bachtiar. Buku 1 edisi kedelapan. Jakarta: Salemba Empat.

Megawati, Ida Ayu Putu, Luh Putu Wiagustini, dan Luh Gede Sri Artini. 2016. Determinasi Keputusan Hedging pada Perusahaan Manufaktur di Bursa Efek Indonesia. E-Jurnal Manajemen Unud

Nuzul, H., \& Lautania, M. F. (2015). Pengaruh Leverage, Financial Distress, dan Growth Options terhadap Aktivitas Hedging Pada Perusahaan Non-Keuangan yang Terdaftar di Bursa Efek Indonesia. Jurnal Dinamika Akuntansi Dan Bisnis, 2(2), 104-113

PRASETYO KURNIAWAN, D. (2018). Analisis Faktor Yang Mempengaruhi Penggunaan Instrumen Derivatif Sebagai Pengambilan Keputusan Hedging Pada Perusahaan Sektor Keuangan Yang Terdaftar Di Bei Periode 2011-2015. Jurnal Ilmu Manajemen (JIM), 6(1), $1-11$

Prasetiono, \& Hidayah, N. (2016). Keputusan Hedging pada Derivatif Valuta Asing (Studi Kasus pada Perusahaan Manufaktur yang Terdaftar di BEI. Diponegoro Journal of Accounting, 5(3).

Prasiwi, K. W. (2015). Pengaruh Penghindaran Pajak Terhadap Nilai Perusahaan: Transparansi Informasi Sebagai Variabel Pemoderasi. In Fakultas Ekonomika dan Bisnis Universitas Diponegoro.

Putro, S H. 2012. Analisis Faktor Yang Mempengaruhi Penggunaan Instrumen Derivatif Sebagai Pengambilan Keputusan Hedging. Diponegoro Business Review, 1(1): 1 -11

Rahmadini, M., \& Darminto, D. P. (2020). Struktur Modal dan Determinasi Keputusan Hedging pada Perusahaan Automotive and Allied Products kebijakan deviden, liquidity tidak memiliki pengaruh secara signifikan terhadap hedging sedangkan firm size memiliki pengaruh secara signifikan terhadap hedgi. 7(1), 35-42 
Reni Utami Dewi, K., \& Purnawati, K. (2016). Pengaruh Market To Book Value Dan Likuiditas Terhadap Keputusan Hedging Pada Perusahaan Manufaktur Di Bei. E-Jurnal Manajemen Universitas Udayana, 5(1), 255027

Salindri, AE, 2018. (2018). BAB II Tinjauan Pustaka Anemia. Universitas Pasundan, 11-29. http://repository.unpas.ac.id/37105/1/BAB II.pdf

Sasmita, I. E., \& Hartono, U. (2019). Karakteristik Perusahaan, Financial Distress, dan Keputusan Hedging: Studi pada Perusahaan Manufaktur di Indonesia. Jurnal Ilmu Manajemen, 7(1), 1-20

Septavita, N., Nasir, A., \& Ilham, E. (2016). PENGARUH BOOK TAX DIFFERENCES, ARUS KAS OPERASI, TINGKAT HUTANG, DAN UKURAN PERUSAHAAN TERHADAP PERSISTENSI LABA (Studi Empiris Pada Perusahaan Manufaktur Yang Terdaftar di BEI Tahun 2011 - 2013). Jurnal Online Mahasiswa Fakultas Ekonomi Universitas Riau, 3(1), 1309-1323

Sianturi, A. H. (2018). Universitas Sumatera Utara Skripsi. Analisis Kesadahan Total Dan Alkalinitas Pada Air Bersih Sumur Bor Dengan Metode Titrimetri Di PT Sucofindo Daerah Provinsi Sumatera Utara, 44-48.

Siddiqui, S. A. (2012). Business Bankruptcy Prediction Models: A Significant Study of the Altman's Z-Score Model. Available at SSRN 2128475

Suffah, Roviqotus dan Akhmad Ridwan. 2016. Pengaruh Profitabilitas, Leverage, Ukuran Perusahaan dan Kebijakan Dividen pada Nilai Perusahaan. Jurnal Ilmu dan Riset Akuntansi : Volume 5, Nomor 2

Sugiyono. 2014. Metode Penelitian Bisnis.Bandung: Alfabeta Sugiyono. (2015). Statistika Untuk Penelitian. Bandung: Alfabeta.

Sugiyono. 2016. Metode Penelitian Kuantitatif, Kualitatif, dan R\&D. Bandung: Alfabeta

Syafril, \& Fahmi, M. (2021). PERUSAHAAN TERHADAP STRUKTUR MODAL PADA BARANG DAN KONSUMSI Abstrak. Jurnal Akuntansi Bekelanjutan Indonesia, 4(1), 92-103

T. R. Jinkar, "Analisa faktor-faktor penentu kebijakan Cash Hlding," E-Journal Akunt. Fak. Ekon. Univ. Indones., 2013

TRI ADITYA, A., \& ASANDIMITRA HARYONO, N. (2018). Pengaruh Leverage, Likuiditas, Market To Book Value, Financial Distress, Dan Firm Size Terhadap Keputusan Hedging (Studi Perusahaan Sektor Consumer Goods Industri Periode 20112016). Jurnal Ilmu Manajemen (JIM), 7(2), 334-343.

Wiagustini, Ni Luh Putu. 2013. Manajemen Keuangan. Udayana Press.

Widarjono, A. (2013). Ekonometrika Pengantar dan Aplikasinya. Yogyakarta: UPP STIM YKPN

Yulandani, F., Hartanti, R., \& Dwimulyani, S. (2018). pengaruh profitabilitas dan ukuran perusahaan terhadap nilai perusahaan dengan CSR sebagai variabel pemoderasi. Seminar Nasional I Universitas Pamulang

Winedy. Terdaftar, Y., Bei, D. I., Manajemen, J., \& Bisnis, F. (2017). Calyptra: Jurnal Ilmiah Mahasiswa Universitas Surabaya Vol.6 No.1 (2017). 6(1), 866-885. 